\title{
UMA PASSAGEM
}

Phabulo Mendes é estudante de pós-graduação na USP em literatura portuguesa.

E-mail: phabulomendes@hotmail.com

O caso da mulher é que ela não tem noção da vida, muito menos do marido. Repetia a mulher para o desconhecido que acabara de conhecer na última estação. Ou melhor, porque ele sentou ao seu lado e sua expressão não era comedida e reservada, ela logo deu ares de conversa. Então, eu é que não queria algo assim, as nove horas da manhã já com bafo de cachaça. Ele, o seu interlocutor, nem ouvidos; balançar de cabeça mais como pedido de socorro do que confirmação ou atenção na conversa. Não. É por isso que as mulheres sofrem. Algumas, eu não. Homem comigo não tem vez. Logo cedo, nem amanheceu o dia e já bêbado. Percebia-se que ela gostava de empregar era mesmo a palavra bêbado. Quem sabe por se tratar de uma proparoxítona. Mas insistia naquela como para manter a todo custo sua conversa. As frases dela possuíam uma dicção pausada. Um entender melhor cada sílaba. Ela respeitava as palavras mesmo sem o saber, porque o que queria na verdade era desabafar. Contar a experiência da vida. Como é cansativo, não? E ainda este metrô. Cheio. Nem bem ela esguelhava o rapaz que a escutava gestualmente, como também, ora ora, procurava com pequenas fisgadas alguém, no vagão onde estava, interessado em sua falácia. E a mulher que agora trabalha comigo. Não é que começou a pirar. Enlouqueceu mesmo. Não é essa moda de depressão. Ela tá é internada. Com o entrar e sair de pessoas, no prosseguir das estações e ele ainda lá, ao seu lado, fiel, com o balançar de cabeça, atento mesmo, em certo sentido. Ela, então, começou a sentir algo diferente. Era uma coisa dentro de si mesma. Articulava vagarosamente, mas agora com um gesto manual em torno dos olhos. Para erguer mais a expressão, talvez? Assim, prosseguia. O barulho das pessoas e os olhares. Despreocupados. Ávidos por chegar ao trabalho e enfrentar mais um dia o chefe e os clientes. Ela, não. Eu só limpo. É um escritório. Todo mundo já me conhece. Tem cada um lá. É cada história. Usava um batom, que só agora, com o avançar da conversa começava a preocupar-se se ele, o batom, estaria ainda na boca. Ela, uma mulher que cuida tão bem da boca, principalmente do que sai dela. Mas o que não suporto mesmo é gente que não tem responsabilidade. Sabe? A conversa agora progredira bem. Ele, ali. Ela, continuando. Embora não soubesse onde iria chegar, o que mais importava-a era segurar a conversa. O ritmo. Não empregaria esta palavra porque achava que os outros não entenderiam. Mas tinha ouvido falar, o pessoal do escritório. É um escritório jurídico, tem gentona lá, hum! Alguém uma vez soltou, à toa, ritmo da conversa. Desde esse instante, bastou a ela. Sempre que podia, pronto, colocava um ritmo. Mesmo em casa, falo, tem que ter ritmo. Na vida, com os amigos da gente. Tudo é questão do ritmo. Ele apenas olhou como quem nunca ouvira uma mesma palavra, muitas vezes, em tão pouco tempo. Ela desceria na última estação. É longe. Todo dia a mesma coisa. Já estou acostumada com o ritmo que levo. Tão bem acostumada que ficou naqueles poucos minutos de conversa, ela, cuidadosa, agora com o frio que já tava dando, sei lá onde, resmungou baixo. Conseguiu olhar para ele. Após tanto tempo de conversa. E é tanta tragédia na televisão. Me pergun...to se... é só... de morte... que e...sse povo sa...be... falar. Ela que apenas experimentava o conversar, não sabia mesmo 
se teria assunto para tanto tempo. Se descer comigo, acho que vou perguntar o nome. Já é um começo. Melhor. Mas o homem, mesmo, não falou muito. Nada. E quando somente duas estações para o seu triunfo, ele, subitamente se levanta, calado, assim como entrou. O que vou fazer mesmo quando chegar hoje em casa, cansada, para a janta. Foi somente os restos que ele ouviu vindo da boca dela. 